\title{
The trouble with \\ 'truth' \\ On the politics of life and death in the assessment of queer asylum seekers
}

BY Marie Lunau

\begin{abstract}
This article explores death and dying in the context of queer migration by reflecting on the ways in which queer asylum seekers are exposed to various forms and manifestations of death through the process of seeking asylum. The article is based on qualitative interviews with queer asylum seekers in Denmark. Drawing on the concept of necropolitics, the article considers how the politics of truth within the asylum system manage life and death not only by the rejection and deportation of applicants, but also by exposing applicants to a slow death in the temporalities of a prolonged process of seeking asylum. The politics of truth within the asylum system appear to be predicated on ideals of normalised national white queerness and homonormativity that come to determine queer asylum seekers' legitimacy and access to inclusion. Queer migrants' paths to protection play out in a geopolitical context where the hope of life, asylum and citizenship are infused with deathly practices and normative imaginaries of truthful queerness.
\end{abstract}

\section{KEYWORDS}

Necropolitics, queer migration, un/grievable lives, geopolitics, homonationalism. ests include feminist and queer theory, de-colonial studies and narratives. 


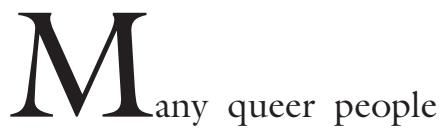
are subjected to physical, sexual and verbal acts of discrimination by state authorities, communities or their families, which compel them to flee from persecution and seek protection elsewhere (UNHCR 2008). The UN Refugee Convention dating back to 1951 stipulates that asylum may be given to a person who has a "well-founded fear of being persecuted for reasons of race, religion, nationality, membership of a particular social group, or political opinion" (UNHCR 2010, 14). Adopted from the Convention, the Danish Aliens Act, Section 7 (1), recognises sexual orientation and gender identity as causes of persecution and, therefore, as grounds for asylum under the category of belonging to a "particular social group" (The Danish Immigration Service 2017). To be eligible for protection, queer asylum seekers must prove both a "well-founded fear of persecution" and that they are members of "a particular social group". These two conditions establish the terms of inclusion and exclusion in the politics of legitimacy and truth in Danish asylum policies.

In Denmark the asylum procedure begins when the applicant is registered by the police. The first interview takes place with the Immigration Service whereby the applicant provides "information and motivation" for their asylum claim. The applicant can in theory be granted asylum after this first interview, but according to the Danish organisation LGBT Asylum, ${ }^{1}$ this is very unlikely. In most cases, a second interview with the Immigration Service follows during which the applicant tells their story and provides evidence. According to the participants in this study, applicants may be subjected to multiple interviews in this phase of the asylum process before the case is either accepted or rejected. If the applicant is rejected, the case automatically proceeds to the Refugee Appeals Board and the state provides the asylum seeker with a lawyer. If the resultant case is rejected, the asylum seeker must leave Denmark within 15 days (LGBT Asylum 2017).

Unlike applicants seeking asylum on the basis of political opinion, race, nationality or religion, for which there is usually some form of evidential documentation of group membership, queer asylum seekers rely entirely on their personal narratives. It is, however, often difficult for queer asylum seekers to translate their identities into the kind of narratives that are recognisable by the state (Lewis 2013). Research in queer migration shows that a significant number of queer asylum claims are rejected because their claimed sexual orientation and/or gender identities are disbelieved (Berg and Millbank 2009; Jansen and Spijkerboer 2011). As Eithne Luibhéid (2008) notes, the state's understanding of sexual and gender variance is limited and rooted in stereotypes that lead migration authorities to decide which bodies are deemed worthy for protection through mechanisms that operate via race, gender, and sexualitybased exclusions.

Similar findings have appeared in a Scandinavian context. A Norwegian study, addressing the relationship between sexual norms and constructions of 'Norwegianness' has found that certain forms of "affect alignment" with 'Norwegian' sexual expressions have become a prerequisite for the granting of asylum (Mühleisen et al. 2012). The scholar Deniz Akin (2017) further addresses how queer asylum seekers are often forced to strategically translate their sexuality and enact a 'rainbow splash' on their lives in order to fit in and to become intelligible queers for the Norwegian authorities. Akin makes use of the concept 'rainbow splash' to reveal how queer asylum seekers are expected to perform "loud and proud" expressions of sexual identity (2017, 463). LGBT Asylum's 2015 report 
points to similar tendencies in Denmark whereby queer asylum seekers are forced to align with normative perceptions of queer identities and lifestyles to become readable within the Danish asylum system. The available data makes it impossible to retrieve the exact acceptance percentage for queer asylum seekers. However, the difficulties of passing as queer is highlighted by LGBT Asylum which states that only 34 of their 181 members were granted asylum in Denmark from 2013-2015 (LGBT Asylum $2016,4)$.

In this article I aim to make visible the various forms of death and dying that queer asylum seekers experience in the process of seeking asylum in Denmark. I will argue that the politics of truth within the Danish asylum system engenders a politics of life and death in the process of seeking asylum. The article contributes to a growing body of research on queer migration in a Scandinavian context as it explores how normative imaginaries of queerness underpin and sustain notions of truth in the access to citizenship in Denmark.

\section{THE 'TRUTH' OF IDENTITY}

The queer asylum seekers in this study reveal how immigration authorities ${ }^{2}$ forcefully evaluate their sexualities and gender identities according to narrow, binary notions of 'truthful' sexualities and gender identities. Yet, scholars have established that meanings of sexual and gender identities are neither universal nor objective. They can be fluid, contextual, culturally specific and changing over time (Diamond 2000 ), which makes it profoundly paradoxical to establish fixed, standardised measurements for 'true' sexualities and gender identities. In their article, Fassin and Salcedo (2015) argue that the truth of sexual identity is unattainable and, therefore, they suggest a focus on self-identification rather than on the 'truth' of identity.

The burden of passing as 'true' and wor- thy of protection seems to be linked, firstly, to the asylum system's binary understanding and evaluation of sexuality and gender identity and, secondly, to the ways in which this system is orientated around what might be called "institutional whiteness" (Ahmed 2012, 33). Feminist scholar Sara Ahmed writes about how the hegemony of whiteness has institutionalised a certain 'likeness' so that even bodies that might not appear white still have to inhabit whiteness if they are to get 'in' $(2007,158)$. Ahmed uses Jacques Derrida's (2000) concept of 'conditional hospitality' to unpack how people of colour are only conditionally welcome in white spaces (Ahmed 2012, 42). Following from her argument, one can read the Danish 'host' nation as offering hospitality on the condition that its guests identify with the nation's common culture. Through queer theorist Jasbir Puar's (2007) concept of 'homonationalism'3 it can then be understood how nationalist formations of homosexuality work to include only those migrants who embody the 'true' normativity and imaginaries of white queerness. As this article will discuss, the politics of truthfulness within the Danish asylum system makes the lives of those who disturb the very whiteness of being queer, killable.

In the process of determining queer asylum seekers' credibility, notions of truth have come to constitute the politics of how some narratives are recognised and how others are deemed illegitimate and are therefore rejected. This article will explore how queer asylum seekers experience the politics of truth that separate true from false according to the state's establishment of what queerness entails. In what follows, I draw on the theoretical framework of biopolitics (Foucault 2003) and necropolitics $^{4}$ (Mbembe 2003) to consider how regimes of truth about sexuality and gender identity within the Danish asylum process expose applicants to various formations, shapes and processes of death and dying. I 
will examine the spatial aspects of necropolitics by focusing on how the politics of living and dying work in the regulation of queer movement and migration.

\section{ETHICS OF PARTIAL TRUTHS}

This article draws on six qualitative narrative interviews with sexual and gender minority persons seeking asylum in Denmark. The narrative methodology can provide complex explorations of queer asylum seekers' narratives, and how these exist within larger narrative structures of bureaucratic institutions and asylum politics (Gubrium and Holstein 2009). In this sense, narratives can be a way of communicating feelings and experiences that tell something about the narrator's sense of self and the culture within which the self is situated. The narrative methodology also allows for an understanding of how queerness and persecution is experienced in the research participants' past, present and future. I came into contact with the queer asylum seeker Hassan through the organisation LGBT Asylum. We agreed to meet at the asylum centre where he was living. Here, he introduced me to the other participants. The six interviews all took place in the asylum seekers' own private rooms at the asylum centre. In the process of establishing a relation with the participants, I found that my own sexual identity as queer was of great importance for building trust and understanding. The participants had fled from West Africa, Southeast Asia and from the Middle East. Maintaining a sense of privacy and confidentiality was essential in this study because many of the participants had previously undergone uncomfortable and violent experiences when they disclosed their identities. Through the informed consent process, it was made clear that all identifying information would be kept confidential. I have anonymised the names and the countries that the participants have fled from; regarding the names, I have con- sciously chosen ones that are very common in the regions from which they have fled. The participants have, however, all fled from countries where homosexuality and trans identities are illegal.

By adopting feminist-science studies scholar Donna Haraway's (1990) postmodern version of standpoint epistemology and by focusing on partial perspectives, I was able to position myself as a researcher and person in such a way as to make myself accountable for what I saw. In positioning my own whiteness and queerness within the context of this study, I hope to contribute to an ethical epistemology of location that does not promise ultimate or objective truths (Haraway 1990). Notions of truth are also central to this article as they relate to the assessment and evaluation of the participants' sexualities and gender identities. The asylum system's assumed objective methods of judging and weighing truths against untruths in queerness is a technique I steered away from during the research process. I was thus less interested in investigating the truth of queer asylum seekers' narratives and more interested in exploring how they experience the politics of truth within the asylum regime, and what this means for their liveability.

\section{ON THE PRIDEFUL QUEER}

All research participants' narratives were judged as not true by the Danish Immigration Service, and their asylum claims were subsequently rejected. Their stories illustrate the extent to which conventions of national normalised truths about queerness dictate which truths are sufficient and which can simply be rejected. During the interview with the queer asylum seeker Ibrahim our conversation focused on his frustration with his application for asylum being rejected based on his sexual orientation. Ibrahim expressed how he tried to show the Immigration Service that he was gay: 
"I show them, I bring my make-up, so they can see $(. .$.$) If you are gay, you know you are$ gay, because it is my way - the way I talk, wear make-up and remove all my hair, all this is the proof." (Ibrahim)

Here, Ibrahim makes use of stereotypical notions and traits of the homosexual male figure in order to convince the immigration authorities that he conforms to those conventional assumptions. Ibrahim further linked his "sensitivity" as evidence for his sexuality: "I am very sensitive. This is a real gay! You must have more emotion!" I am not interested in determining what "real gay" is, but what is interesting here is the way in which Ibrahim tries to present himself as 'recognisably' gay within the system's framework in order to become a worthy subject of asylum. I do not, however, insinuate that Ibrahim does not feel like a "real gay" according to the standards he mentioned, but his very emphasis indicates that the asylum system requires a "real gay" narrative that adheres to normalised notions of queerness.

If we analyse the reasons why the asylum seeker Hassan's plea for asylum based on his sexual orientation was rejected, the narrow notion of 'true' queerness becomes visible. Hassan grew up in West Africa with his mother, father and five sisters. Hassan was forced to flee to another country in West Africa after he was publicly tortured and humiliated by his community when they discovered that he was having sex with men. After fleeing, Hassan married a woman to cover for his sexuality. In the rejection letter sent to him, the Immigration Service stated that it did not seem "convincing or plausible" that Hassan married a woman to cover for his sexuality. During the formal interview, they further suggested that if Hassan was "really gay" he could have avoided the pressure to get married from the community by 'coming out' as gay. Hassan expressed confusion as to why the immigration authorities were not able to take his cultural context into consideration when evaluating his case. He told me that it would have been a greater risk to stay single. Instead of trying to understand the dangers of 'coming out', the immigration authorities expected Hassan to fit the Danish liberal narrative of being proud about one's sexuality. ${ }^{5}$

Many of the applicants expressed how they felt forced and expected to present feelings of pride when they interacted with the Danish asylum authorities. They felt that shame and pride were expected to exist as opposites: shame should be attached to the past and pride to the present and future in Denmark. Ibrahim, who had fled from the Middle East, described this dualism when he told me to put my hands in front of my eyes to feel the darkness and after a little while to remove my hands and look into the light of the sun. He used this metaphor to show me how the sun blinds him. The meaning of the shining sun, Ibrahim elaborated, was the expectation of being visible and proud in Denmark. But Ibrahim was critical of this pride narrative that permeates the national understanding and expectations of homosexuality as he mentioned how shame might remain as a permanent, structuring feeling of his sexuality - even in Denmark.

Many of the queer asylum seekers felt that they were expected to present this preferred narrative of pride as evidence during interviews with the authorities. This exemplifies how expressions of sexual and gender identities are accepted and regulated according to Danish normative notions of race, sexuality and gender. Following Ahmed (2007, 157), we can understand these assumptions about the 'right' kind of queerness as the way in which institutions are shaped by whiteness, which makes nonwhite bodies feel exposed, visible and different. As such, the institutional whiteness embedded within the Danish asylum's politics of recognition establishes a 'true' queer identity by which the truthfulness of the 
asylum seekers' stories are measured for their similarity to whiteness. When the asylum seekers' ways of performing queerness do not fit the national norms of 'proud' white queerness, they trouble the truth which in turn threatens their legitimacy and access to inclusion.

Following the work of Puar (2007), Danish scholar Michael Nebeling Petersen (2016) locates the concept of homonationalism within a Danish context. He exemplifies how the Danish legislation has included queer people in the right to marry and to reproduce. However, as he argues, the problem with becoming 'normal' is the construction of new and performative hierarchies between the good and the bad citizen. In a discussion of what the Danish narrative of 'frisind' (liberalism) does, Nebeling Petersen argues that it produces a distinction between 'Danishness', liberalism and gay rights on the one side and 'nonDanishness', non-liberalism and homophobia on the other. So when queer applicants do not express queerness in the 'Danish' sense, they can be rejected without threatening the national identity and narrative that protect the civil rights of queer people. According to the queer asylum seekers in this study, the truth-seeking logic against the backdrop of which they are measured seems to be composed in an image of an institutional whiteness that frames and formulates 'true' queerness, which then designates who is worthy of salvation and who is instead vulnerable "either to actual death or to the slow draining away of life" (Lee and Pratt 2012,891).

\section{DEATH IN THE MIDST OF LIFE}

The queer asylum seeker Fatimah came to Denmark for a conference with her colleague to present their work in LGBT communities in West Africa. Fatimah decided to extend her stay by a couple of days before returning home. During this time she received a phone call from a police officer in her home country who told Fatimah that her colleague had been arrested and killed upon her arrival because they had been "promoting homosexuality". The police officer (who had helped Fatimah before) advised her not to return home. The threat of deportation was overwhelmingly present in Fatimah's story as it so patently related to the possibility of being killed. Her narrative illustrates how the asylum system's decision and evaluation of her claim based on her sexual orientation has fatal implications:

"You get rejected, that means it is the end of you (...) If I get positive I still have my life, but if I get negative [rejection] that is the end of it. I hope I have got the chance to live again." (Fatimah)

By voicing the hope to have a "chance to live again", Fatimah makes a distinction between being alive and living a life in which it is implied that even though she is alive, she is living in the shadow of a possible, potential death. Fatimah's interpretation of the asylum system's institutional power to either end life or give life resonates with the queer asylum seeker Milad's perspective that the legal decision can either "kill someone or give someone a new life". When Milad received his rejection letter for asylum based on his sexual orientation, he attempted to commit suicide. A friend found him in the bathroom of the asylum centre and called an ambulance. Fatimah, much like Milad, felt that if she was not granted asylum by the Danish state she would end her life. Their stories point to the consequences of the asylum system's decisions to either believe or disbelieve applicants' identities.

Ibrahim introduced the topic of Danish state power by saying: "In Denmark or in Europe they never can kill you", but he then reframed his point: "In my country, you know what makes a reason to kill you, but here in Denmark that reason is: they give you the negative". Ibrahim compares 
his experience of the way in which his country in the Middle East kills with the rejection of asylum in Denmark which too feels like an act of killing. Where Ibrahim comes from, the authorities have the right to perform a direct, actual killing after a person's fourth conviction of homosexual behaviour. However, in Denmark, as Ibrahim suggests, the authorities cannot kill queer asylum seekers overtly: instead, the system 'kills' them by denying them asylum (i.e. the right to residence due to refugee status) in Denmark. As a consequence, the asylum seekers either have to return to their home countries where an active violent death is probable or, alternatively, they might, like Milad and Fatimah, (try to) commit suicide.

The regulation of life can be analysed via philosopher Michel Foucault's (2003) concept of 'biopower' which describes the way in which the contemporary world is governed by mechanisms that operate on and through our bodies. The asylum regime can be understood as a system that uses technologies of biopower either to protect or to neglect certain individuals and populations. According to Foucault, there is a shift from sovereign power, which can "take life" and "let live" to biopower which has the new right to "make live" and "let die" (2003, 240-41). Foucault's concept of biopolitics can help to unpack Ibrahim's observation of the way in which Denmark does not 'take life' in the literal form of killing, rather it 'lets die' by subjecting rejected asylum seekers to displaced forms of death. The implication is that asylum seekers are 'let to die' if they do not fit and inhabit national ideals of 'true' normalised white queerness.

Philosopher and political theorist Achille Mbembe offers the concept of 'necropolitics' which can be interpreted as a form of power that produces social relations of living and dying such that some are led into the worlds of life while others are directed into "death-worlds" (2003, 40). Death- worlds describe "new and unique forms of social existence in which vast populations are subjected to conditions of life conferring upon them the status of living dead" (Mbembe 2003, 40). Fatimah and Ibrahim's articulations of how death seeps into their lives draws attention to the deadly distinction between those queers who are marked for life and those left outside state protection subjected to death-worlds. Fatimah is permanently standing in the shadow of death while living and Ibrahim is perpetually faced with the risk of a double formation of death: the figurative death by being denied asylum in Denmark and the potential and actual death with which the government of his country of origin threatens him.

In the following, I explore how the politics of truth within the asylum system manage life and death not only by rejection and deportation of applicants, but also by exposing them to slow and invisible manifestations of death. I will thus observe the space between life and death, a liminal space in which queer asylum seekers are not actively killed, but rather are doomed to what Lauren Berlant calls a 'slow death' (2007). I use slow death to point to the subtle and slow forms of death and dying that are experienced by queer asylum seekers in the prolonged process of seeking asylum.

\section{BETWEEN LIVING AND DYING: WAITING TO BE RECOGNISED}

The waiting time between interviews with immigration authorities and receiving rejections of asylum claims have been described by asylum seekers as an in-between zone where they have no rights. In this space of waiting to be recognised, they express how everyday forms of violence, death and dying come to operate in hidden and invisible ways. The participants in this study told me about the ways in which they experienced this; according to Danish legislation, they 
do not have permission to work, and they also have limited access to health care and financial support. They talked about ongoing experiences of harassment in the refugee camps and that they were constantly moved from one refugee camp to another. They expressed how they found themselves located in an uncertain space of nonexistence in the makeshift world between inclusion and rejection, between life and death, while waiting to be recognised. The everyday practices of immigration policies have led many of the queer asylum seekers with whom I spoke to depression, anxiety and suicide attempts. Below, Fatimah tells how she experienced the process of seeking asylum and how this process creates conditions of torture, invisibility and death:

"I am sure by the time I die they will give me residency to give me a place to get buried. If you don't care about me when I am alive, how about when I die? How would you care about me? Because you are torturing me. The asylum system is torture. In the sense that it makes you lose your mind and you can die at any time. We have people who die in the asylum system and they were here to seek protection." (Fatimah)

Fatimah's story tells us how the mental torture inflicted upon her by the asylum process produces emotional debility in the form of invisibility that allows her suffering and deprivation to be unseen, or in short, for her life to go unrecognised. Fatimah's reflection on how the asylum system does not care for her while she is alive points back not only to the ways in which the asylum regime promotes an experience of being a 'living dead', it also underlines how her rights are suspended during the process of seeking asylum. Political philosopher Hannah Arendt (1986) writes that when people are excluded from the protection of nation-states, it excludes them from the right to have rights. Arendt further argues that the "right to have rights" is condition- al and "enjoyed only by citizens of the most prosperous and civilized countries" (1986, 279). Fatimah's question of whether the state will care for her when she dies involves the very experience of not having the right to be cared for while she is alive. Frustrated with waiting for the outcome of her claim for asylum over several years, Fatimah told me:

"I call it a civilised prison because you are not being chained to jail, but you have been in a system where you don't have freedom, you don't have access to a lot of things, and at the end of the day, you go through self-torture. You can see someone being in an asylum camp for three years. After that waiting period, all of a sudden, they have just been given a negative. You can't keep somebody in a camp and do an interview one month and then you wait for two years before you interview that person again. You expect the person to be normal after that waiting period? Let's just say you put a dog inside the house and you only give it a meal one time of the day. Do you think the dog will be nice to you? No. Because it has already seen that you are not a nice person because you are trying to deprive it from its rights and what it needs. So you can't put an asylum seeker in a room and then you expect that person to just fold hands and wait.” (Fatimah)

These living conditions that Fatimah voices engender a tempo of injustice and suspension of rights apparent through her precarious living conditions and in the seemingly endless time spent awaiting the outcome of her claim. The difference regarding the value ascribed to the life of different population groups is noticeable in the everyday conditions of refugee life. Feminist philosopher Judith Butler argues that there is no such thing as life itself because life "requires conditions in order to become livable life and, indeed, in order to become grievable" (2009, 23). Fatimah's experience indicates that the value placed on her 
life is something other than a life to be grieved. Fatimah's experience shows how she feels trapped between life and death:

"I think to myself: You should keep on pushing, you have gone far, but at some point in my mind someone is telling me: For what? Why are you doing this? You are in a place where you don't even know if you will get protection or not. Why are you living?" (Fatimah)

This uncertainty of life demonstrates how certain people are forcefully positioned in a state between life and death. Fatimah's experience of 'death-in-life' (Mbembe 2003) emerges from the abject conditions to which she is exposed during her process of seeking asylum. This position can be interpreted as a political technology of suffering that subjects her to conditions of being "kept alive but in a state of injury" (Mbembe 2003,21$)$. The enforcement into this space where questions of "why am I living?" are sustained brings to the fore the permanent wounding when asylum seekers are deprived of the ability to imagine the future. The shifting boundaries between life and death suggest that under the conditions of necropolitics, the lines between hope and giving up, resistance and suicide are blurred and precarious. These blurred lines between life and death are further apparent in the story of the transwoman Amirah when she describes the asylum system's denial of giving her hormones as a death:

"I cried and told them that I need hormones because if I don't take hormones, I will die. I need hormones for my body. Okay, I am a transwoman, almost for six months - half a year - I did not take them.” (Amirah)

The denial of Amirah's right to her gender identity illustrates how the asylum system invokes a 'slow death' regarding her identity. The state does not only take away Amirah's own terms of self-identification by denying her hormones, but also inadvertently forces her to experience the struggle of living with a slowly dying gender identity. This co-presence of life and death in the stories of Fatimah and Amirah are here manifested in the waiting time of being recognised as either true or false, worthy or not worthy of asylum and protection, liveable or disposable. This space between life and death is not void but imbued with institutional normalised white queerness that constructs a dangerous line between those who are doomed to be 'let to die', and those who deserve to be included in the population and 'made to live'.

The queer migrants' experiences of the asylum system's violence points to the unequal regimes of living and dying. The question of which lives are worth protecting is a moral and political one that points to how lives, deaths and truths are normatively framed and assessed. These politics become particularly visible in instances where one form of queer life fails to conform to the normative expectations of truth. The death-making of queer asylum seekers connects to actual and literal forms of killing as well as to the everyday experience of those perhaps unremarkable but no less cruel forms of death. The queer asylum seekers' stories show how paths to asylum, refugee status, and the right to residency are paved with experiences of suffering that occur with differing intensities in the existence between life and death.

\section{GEOPOLITICAL DEPLOYMENTS OF QUEER LIFE AND DEATH}

Focusing on necropolitics can offer perspectives on how queer migration is a means by which contemporary relations of geopolitical power are structured and maintained. Through the concept of homonationalism, Puar considers how the deployment of the homosexual figure bolsters the construction of national identity in the Global North as a symbol of the na- 
tion's 'greatness' $(2007,51)$. Queer people are not inherently outlaws to the nation: "on the contrary, they have become the emblem of its supposed "tolerance" " (Fassin and Salcedo 2015, 1119). As such, not all queer bodies are positioned outside the heteronormative hegemony but may, in fact, be integral to maintaining forms of nationalism that celebrate queerness as a neoliberal ideal of freedom and liberation (Shakhsari 2014). The Danish state prides itself on its values of acceptance and celebration of sexual diversity, and yet queer asylum seekers are subjected to narrow norms of white queerness in order to be accepted into Denmark. This structural position of being the guest who receives hospitality by the Danish state thus requires one to embody the promise of normalised diversity.

As explored in this article, the way the asylum regime exposes queer migrants to various forms of death reflects not only a form of necropolitics but also what anthropologist and trans activist Elijah Edelman has termed 'homo(necro)nationalism'. The term refers to the ways in which the death of the 'bad', non-normalised queer creates the ideological and physical space for the 'good', normalised queer (Edelman 2014, 174). This highlights how the technology of 'letting die' works to promote homonationalist ideals in the construction of worthy queer citizens (Edelman 2014, 175), which in this case is the queer asylum seeker who successfully fulfils the requirements of becoming a truthful homonormative citizen. Feminist theorist Sima Shakhsari $(2014,103)$ calls this mechanism "the politics of rightful killing", which is an explanation of how "the management of the life of one population relies on the discipline, control and, ultimately, death" of another who threatens the interests of the population whose life is worth saving. In this sense, the "living dead" can be killed "rightfully with rights" insofar as they pose a danger to the national identity (ibid.,
104). Queer asylum seekers who are deemed unassimilable thus become disposable, invisible and marked for death.

This article has highlighted the necropolitical brutality within the politics of asylum as it links the requirement of the 'truthful' queer migrant to policies of letting die. The politics of truth have come to define the legitimate queer asylum seeker according to homonationalist notions of queerness and thus condemn queers who do not fit the normalised standards to deathly conditions of life. The assessment of queer asylum claims draws attention to the deathly logic of the binary truth-seeking strategies by which queer asylum seekers are evaluated. Giving voice to queer asylum seekers' multiple and complex experiences of hope and despair, this article shows that they are forced into an uncertain space between liveliness and deadliness while waiting to be recognised. This article makes visible the everyday 'death-worlds' of queer migrants as well as the spectacular and literal forms of death they experience during the process of seeking asylum in Denmark.

\section{Notes}

1. LGBT Asylum is a support group for queer asylum seekers in Denmark, which offers legal and emotional guidance.

2. In using the wording 'immigration authorities' I refer to the interviewers working for the Danish Immigration Service. It is worth mentioning that I do not aim to reduce the circumstances to a matter of individual prejudice and evaluation but rather as part of an institutional problem.

3. Short for 'homonormative nationalism'.

4. Despite the link between 'necropolitics' and Giorgio Agamben's (1998) 'thanatopolitics', I use Mbembe's theorisation of necropolitics since it locates the power of death-making on the side of the state.

5. It is important to note that not all queer people in Denmark feel 'proud' or 'out' either, including the research participants of this study. 


\section{REFERENCES}

- Agamben, G. 1998. Homo Sacer: Sovereign Power and Bare Life. Trans. Daniel Heller-Roazen. Stanford: Stanford University Press.

- Ahmed, S. 2007. A Phenomenology of Whiteness. Feminist Theory. 8(2), 149-168. DOI: https://doi.org/10.1177/1464700107078139 - Ahmed, S. 2012. On Being Included. Racism and Diversity in Institutional Life. Durham and London: Duke University Press.

- Akin, D. 2017. Queer Asylum Seekers: Translating Sexuality in Norway. Journal of Ethnic and Migration Studies. 43(3), 458-474. DOI:

https://doi.org/10.1080/1369183X.2016.1243 050

- Arendt, H. 1986. The Origins of Totalitarianism. London: Andre Deutsch.

- Berg, L. \& Millbank, J. 2009. Constructing the Personal Narratives of Lesbian, Gay and Bisexual Asylum Claimants. Journal of Refugee Studies. 195-223. DOI:

https://doi.org/10.1093/jrs/fep010

- Berlant, L. 2007. Slow Death (Sovereignty, Obesity, Lateral Agency). Critical Inquiry. 33, 754780. DOI: https://doi.org/10.1086/521568 - Butler, J. 2009. Frames of War: When is Life Grievable? London: Verso.

- Derrida, J. 2000. Of Hospitality. Anne Dufourmantelle Invites Jacques Derrida to Respond. Stanford: Stanford University Press.

- Diamond, L. M. 2000. Sexual Identity, Attractions, and Behavior among Young Sexual-Minority Women over a 2-year Period. Developmental Psychology. 36(2), 241-250. DOI:

http://dx.doi.org/10.1037/0012-1649.36.2.241

. Edelman, E, 2014. 'Walking while Transgender': Necropolitical Regulations of Trans Feminine Bodies of Colour in the US Nations's Capital. In: Haritaworn, J., Kuntsman, A. and Posocco, S. eds. Queer Necropolitics. New York: Routledge, 172 191.

- Fassin, E. and Salcedo. 2015. Becoming Gay? Immigration Policies and the Truth of Sexual Identity. Arch Sex Behav. 44, 1117-1125. DOI: 10.1007/s10508-015-0551-z

- Foucault, M. 2003. "Society must be defended". Lectures at the Collège de France, 1975-76. New York: Picador.

- Gubrium, J. and Holstein, J. A. 2009. Analyzing Narrative Reality. Thousand Oaks, CA: Sage. - Haraway, D. 1990. Simians, Cyborgs, and Women: The Reinvention of Nature. New York: Routledge.

- Jansen, S. and Spijkerboer, T. 2011. Fleeing Homophobia. Asylum Claims related to Sexual
Orientation and Gender Identity in Europe. COC Netherlands and Vrije Universiteit Amsterdam.

- Lee, E. and Pratt, G. 2012. The Spectacular and the Mundane: racialised State Violence, Filipino Migrant Workers, and their Families. Environment and Planning. 44, 889-904. DOI:

https://doi.org/10.1068/a4448

- Lewis, R. 2013. Deportable Subjects: Lesbians and Political Asylum. Feminist Formations. 25(2), 174-194. DOI: 10.1353/ff.2013.0027

- LGBT Asylum. 2015. LGBT Asylum Applicants in Denmark. Applying for Asylum on Grounds of Sexual Orientation and Gender Identity. LGBT Asylum.

- LGBT Asylum. 2016. LGBT Asylum i tal-statistik 2013-2015. LGBT Asylum.

- LGBT Asylum. 2017. The Asylum Procedure in Denmark. [Online]. [Accessed March 7 2019]. Available from: https://www.lgbtasylum.dk/wpcontent/uploads/2014/12/Asylskema-engmaj14.pdf

- Luibhéid, E. 2008. Queer/Migration: An Unruly Body of Scholarship. GLQ: A Journal of Lesbian and Gay Studies. 14, 169-90. DOI:

https://muse.jhu.edu/article/241318

- Mbembe, A. 2003. Necropolitics. Public Culture. 15(1), 11-40. DOI:

https://doi.org/10.1215/08992363-15-1-11

- Mühleisen, W., Røthing, Å. and Bang Svendsen, S. H. 2012. Norwegian Sexualities: Assimilation and Exclusion in Norwegian Immigration Policy. Sexualities. 15(2), 139-155. DOI:

https://doi.org/10.1177/1363460712436540

. Nebeling Petersen, M. 2016. "These are queer times indeed" - en introduktion til homonationalisme i en dansk kontekst. Women, Gender and Research. 25(4), 55-66.

- Puar, J. K. 2007. Terrorist Assemblages. Homonationalism in Queer Times. Durham \& London:

Duke University Press.

- Shakhsari, S. 2014. Killing Me Softly with your Rights: Queer Death and the Politics of Rightful Killing. In: Haritaworn, J., Kuntsman, A. and Posocco, S. eds. Queer Necropolitics. New York: Routledge, 93-110.

- The Danish Immigration Service. 2017. What are the Requirements for being granted Asylum? [Online]. [Accessed March 7 2019]. Available from: https://www.nyidanmark.dk/en-GB/Youwant-to-apply/Asyl/Voksen-asylansøger - UN High Commissioner for Refugees (UNHCR). 2008. UNHCR Guidance Note on Refugee Claims Relating to Sexual Orientation and Gender Identity. [Online]. [Accessed March 7 2019]. 
Available from: http://www.refworld.org/docid/48abd5660.html

. UN High Commissioner for Refugees (UNHCR). 2010. Convention and Protocol Relating to the Status of Refugees. [Online]. [Accessed March
7 2019]. Available from: http://www.refugeelegalaidinformation.org/sites/default/files/uploads $/ 1951 \% 20$ convention $\% 20$ and $\% 201967 \% 20 \mathrm{pr}$ otocol.pdf 